\title{
Penetapan Tarif Ambulans Untuk Evakuasi Medis Berbasis Unit Cost (Penelitian di AGD Dinas Kesehatan DKI Jakarta)
}

\section{Kelvin E Riupassa. ${ }^{1}$, Narizma Nova ${ }^{2}$, Endah Lestari ${ }^{3}$, Sri Juniarti Azis ${ }^{4}$, Wahyu Sulistiadi ${ }^{5}$}

ini.dr.kelvin@gmail.com ${ }^{1}$, narizmanova@gmail.com², endh.lest@gmail.com ${ }^{3}$, yuni.azis3@gmail.com ${ }^{4}$, wahyufphui@gmail.com ${ }^{5}$, Universitas Indonesia, Indonesia

\begin{abstract}
Background:

An ambulance is a vehicle designed to be able to handle emergency patients, provide first aid and carry out intensive care while on the way to a referral hospital. Ambulance operations require a large amount of funds obtained from APBD funds through tariffs that were passed through the DKI Jakarta Governor Regulation five years ago. For this reason, a new tariff is required to adjust to current conditions.

Objectives:

The purpose of this study is to calculate the unit cost of ambulance services in DKI Jakarta to be a consideration in the tariff setting policy in DKI Jakarta province.

Research Metodes:

This study uses a quantitative descriptive approach to obtain information about the unit cost of the Jakarta ambulance production unit. The method used is the calculation of real cost using the basis of the causes of costs. This research was conducted at the DKI Jakarta Emergency Ambulance using secondary data on investment costs, operational costs and maintenance costs in 2018.

Results:

The total cost of emergency ambulance in 2018 is known that the proportion of three cost components, namely operational costs, is $76 \%$, followed by investment costs of $20 \%$ and maintenance costs of $3 \%$. The calculation of the total cost of medical evacuation using the double distribution method is Rp. 98,915,016,805.00 divided by the number of medical evacuations in 2018 of 37,564 activities, the unit cost of medical evacuation for the AGD of DKI Jakarta Health Office is Rp. 2,633,215.00 without subsidies. APBD costs, while if the subsidy component is included in the calculation, the unit cost for one trip to the AGD of the Health Office is Rp. 604,071.00. This is still far above the current tariff of Rp. 450.00, so the cost recovery rate (CRR) is still below. $100 \%$.

Conclusion:

From the three cost components consisting of investment, operational and maintenance costs, the largest proportion was operational costs at $76 \%$. The Cost Recovery Rate has not reached $100 \%$ so that the existing rates have not covered the costs incurred.
\end{abstract}

Keywords: ambulance; price fixing; unit cost

\begin{abstract}
Abstrak
LatarBelakang:

Ambulans merupakan kendaraan yang didesain untuk dapat menangani pasien gawat darurat, memberikan pertolongan pertama dan melakukan perawatan intensif selama dalam perjalanan menuju rumah sakit rujukan. Operasional ambulans membutuhkan dana yang besar didapat dari dana APBD melalui tarif yang disahkan melalui Peraturan Gubernur DKI Jakarta lima tahun yang lalu. Untuk itu dibutuhkan penetapan tarif baru yang menyesuaikan dengan kondisi saat ini.
\end{abstract}

Tujuan :

Tujuan penelitian ini adalah untuk menghitung unit cost pelayanan ambulans di DKI Jakarta untuk menjadi pertimbangan dalam kebijakan penetapan tarif di provinsi DKI Jakarta.

Metode Penelitian:

Penelitian ini menggunakan pendekatan deskriptif kuantitatif untuk mendapatkan informasi mengenai unit cost pada unit produksi ambulans DKI Jakarta. Metode yang dipakai adalah perhitungan real cost dengan menggunakan dasar penyebab biaya. Penelitian ini dilakukan di Ambulans Gawat Darurat DKI Jakarta menggunakan data sekunder pada biaya investasi, biaya operasional dan biaya pemeliharaan Tahun 2018 .

Hasil :

Total biaya ambulans gawat darurat Tahun 2018 diketahui bahwa proporsi dari tiga komponen biaya yaitu pada biaya operasional yaitu $76 \%$, diikuti biaya investasi sebesar $20 \%$ dan biaya pemeliharaan $3 \%$. Perhitungan total biaya evakuasi medis dengan metode double distribusi sebesar Rp.98.915.016.805,00 dibagi jumlah evakuasi 
medis di tahun 2018 sebanyak 37.564 kegiatan didapatkan unit cost evakuasi medis AGD Dinkes DKI Jakarta satu kali perjalanan adalah Rp.2.633.215,00 apabila tanpa subsidi biaya APBD sedangkan apabila komponen subsidi dimasukan dalam perhitungan didapatkan unit cost untuk sekali perjalanan AGD Dinkes adalah Rp.604.071,00., masih jauh di atas tarif yang berlaku saat ini sebesar Rp.450.00,00 sehingga cost recovery rate (CRR) nya masih dibawah $100 \%$.

\section{Kesimpulan:}

Dari tiga komponen biaya yang dianalisa terdiri dari biaya investasi, operasional dan pemeliharaan didapatkan proporsi terbesar adalah biaya operasional sebersar 76\%. Adapun Cost Recovery Rate (CRR) tarif yang sudah ada saat ini masih belum mencapai $100 \%$ sehingga tarif yang ada belum menutupi biaya yang dikeluarkan.

Kata kunci: ambulans; penetapan tarif; unit cost

\begin{tabular}{l|ll}
\hline DOI & $:$ & $10.24903 / \mathrm{kujkm} . \mathrm{v} 7 \mathrm{i} 1.1186$ \\
\hline Received & $:$ & October 2020 \\
\hline Accepted & $:$ & October 2020 \\
\hline Published & $:$ & June 2021 \\
\hline
\end{tabular}

Copyright Notice

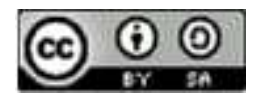

This work is licensed under Creative Commons Attribution 4.0 International License.

\section{PENDAHULUAN}

Daerah Khusus Ibukota Jakarta merupakan daerah ibukota dengan kepadatan penduduk yang berjumlah lebih dari 11 juta jiwa. Keberagaman etnis, agama, budaya dan geografis menyebabkan rentan akan timbulnya masalah seperti bencana alam, kejadian luar biasa serta kerusuhan. Kejadian luar biasa, kerusuhan dan bencana alam seperti gempa dan banjir dapat mempengaruhi keamanan dan kestabilan nasional. Mengingat hal tersebut, maka diperlukan suatu sistem Penanggulangan bencana dan kejadian luar biasa untuk menjamin keamanan dan kestabilan nasional.

Koordinasi dan kerjasama di lingkungan instansi Pemerintah Daerah
DKI Jakarta akan menentukan keberhasilan penanganan kejadian luar biasa, bencana alam dalam hal keamanan dan khususnya bidang kesehatan. Ambulans Gawat Darurat (AGD) Dinas Kesehatan adalah salah satu unit pelaksana Teknis Dinas Kesehatan DKI Jakarta sesuai dengan Peraturan Gubernur DKI Jakarta Nomor 384 Tahun 2016 yang bertugas untuk melakukan pengelolaan pelayanan ambulans gawat darurat bagi masyarakat, instansi pemerintah, /swasta, organisasi dan event di wilayah Jakarta dan sekitarnya. Unit ini merupakan garda terdepan dalam penanganan masalah kesehatan khususnya pra Rumah Sakit.

Agar operasionalisasi AGD dapat berjalan dengan optimal maka diperlukan 
pendanaan yang baik. Pendanaan AGD didapat dari Anggaran Pendapatan dan Belanja Desrah Provinsi DKI Jakarta dan dari masyarakat yang diperoleh melalui pemberlakuan tarif layanan yang disahkan oleh Gubernur DKI Jakarta. Tarif layanan yang ada saat ini berdasarkan Peraturan Gubernur DKI Jakarta Nomor 209 Tahun 2015 dan belum diperbaharui setelah lima tahun disahkan. Tarif yang ada sudah tidak lagi mencerminkan kebutuhan dan biaya layanan aktual saat ini sehingga penting untuk memperbaharui tarif layanan AGD Dinkes DKI Jakarta.

Biaya aktual (actual cost) adalah biaya yang terjadi (biaya historis masa lalu) yang dibedakan dari biaya yang dianggarkan (budget cost) yang merupakan biaya yang diprediksi atau diramalkan (biaya masa depan). Sebelum membuat suatu keputusan, sebaiknya perlu diketahui berapa biaya suatu hal seperti biaya produk, mesin, layanan atau proses. Kita menyebut hal ini sebagai obyek biaya (cost object) untuk menunjukkan sesuatu yang biayanya ingin diukur (Horngren, 2006).

Jenis-jenis biaya dapat dibagi menjadi biaya berdasarkan alokasi, biaya berdasarkan sifatnya, biaya satuan unit, biaya investasi dan biaya operasionalpemeliharaan (Horngren, 2006). Biaya berdasarkan alokasi terdiri dari biaya lagsung (direct cost) dan biaya tidak langsung (indirect cost). Biaya berdasarkan sifatnya terdiri dari biaya variabel (variabel cost) dan biaya tetap (fixed cost). Sedangkan biaya satuan unit terdiri dari biaya total (total cost) dan biaya satuan (unit cost).

Biaya investasi biasanya berhubungan dengan pembangunan atau pengembangan infrastruktur fisik dan kapasitas produksi. Perhitungan biasanya dilakukan untuk kurun waktu setahun I"disetahunkan" (annualized investmenst cost atau annualize fixed cost) dengan memasukkan nilai inflasi, nilai masa pakai dan umur pakai (umur ekonomis). Sedangkan biaya operasional adalah biaya yang diperlukan untuk melaksanakan kegiatan dalam suatu proses produksi dan memiliki sifat habis pakai dalam kurun waktu yang singkat (kurang dari 1 tahun).

Ada beberapa metode distribusi biaya yaitu simple distribution ( melihat kaitan biaya dengan unit produksi yang relevan), step down (distribusi dilihat dari unit penunjang ke unit penunjang lain dan unit produksi), double distribution dan multiple distribution.

Cost Recovery Rate (CRR) adalah kemampuan rumah sakit untuk menutupi pengeluaran berdasarkan penerimaan yang diterima rumah sakit. CRR bisa dihitung dengan menghitung selisih antara total pendapatan dengan biaya total dikalikan 100\%. Jika CRR lebih besar dari $100 \%$ 
maka rumah sakit dalam keadaan Surplus dan jika CRR kurang dari 100\% maka rumah sakit berada dalam keadaan defisit (Wita,2012)

\section{METODE PENELITIAN}

Penelitian ini menggunakan pendekatan deskriptif kuantitatif untuk mendapatkan informasi mengenai unit cost pada unit produksi AGD Dinkes DKI Jakarta. Data yang digunakan adalah data sekunder pada biaya investasi, biaya operasional dan biaya pemeliharaan yang dikelompokkan menjadi biaya tetap dan biaya tidak tetap.. Hasil dari biaya tersebut dijumlahkan dan didapatkan biaya total dari beberapa unit di AGD Dinkes DKI Jakarta. Data yang diambil adalah data dari bulan Januari sampai dengan bulan Desember Tahun 2018. Metode yang dipakai dalam perhitungan biaya satuan adalah real cost dengan menggunakan dasar penyebab biaya. Pengolahan dan analisis data dilakukan untuk mendapatkan biaya total dan biaya satuan pelayanan AGD Dinkes DKI Jakarta.

\section{HASIL PENELITIAN}

Dari penelitian yang telah dilakukan didapatkan hasil sebagai berikut:

\section{Total Biaya Ambulans Gawat Darurat}

Total biaya ambulans gawat darurat pada tahun 2018 adalah
Rp.109.415.263.686,00. Komposisi biaya yang ada pada unit penunjang dan unit produksi terbagi menjadi tiga kelompok yaitu biaya operasional, biaya pemeliharaan dan biaya investasi. Dari data yang ada diketahui biaya terbesar ada pada biaya operasional yaitu $76 \%$, diikuti biaya investasi sebesar $20 \%$ dan biaya pemeliharaan $3 \%$.

\section{a. Biaya Investasi}

Biaya investasi terdiri dari biaya investasi gedung, alat medis dan non medis, serta kendaraan AGD Dinkes DKI Jakarta.Biaya investasi alat medic memiliki proporsi terbesar yaitu 39\% diikuti oleh biaya kendaraan sebesar $29 \%$. Hal ini sangat wajar karena bisnis utama AGD Dinkes DKI Jakarta adalah ambulans dimana alat medis dan kendaraan ambulans merupakan asset pokoknya. Sedangkan Annual Invesment Cost Gedung dan alat non medis, masing masing jika dipersentasekan terhadap total cost adalah sebesar $25 \%$ dan $7 \%$.

\section{b. Biaya Operasional}

Proporsi terbesar dari biaya AGD Dinkes DKI Jakarta pada tahun 2018 adalah biaya operasional armada AGD yang berjumlah 60 unit beroperasi 24 jam 7 hari seminggu, mencapai Rp.83.615.555.133, dengan persentase terbesar adalah untuk belanja pegawai, baik gaji maupun non gaji seperti biaya peningkatan kompetensi petugas ambulans, danj uga beberapa belanja yang 
secara langsung mempengaruhi operasional dari AGD Dinkes DKI Jakarta seperti untuk pembelian BBM, ATK, dan beberapa biaya langsung untuk unit penunjang seperti biaya Diklat, Marketing, unit Mutu, serta biaya pengeluaran untuk telepon, air, listrik dan internet.

\section{c. Biaya Pemeliharaan}

Biaya pemeliharaan memiliki proporsi $3 \%$ dari total biaya yaitu Rp.3.683.840.678,00. Pemeliharaan tersebut dilakukan untuk alat medik, kendaraan, dan gedung AGD Dinkes DKI Jakarta.Pemeliharaan kendaraan memiliki porsi terbesar dari $35 \%$ dari total biaya pemeliharaan.

\section{Unit Cost Evakuasi Medis dengan}

\section{Ambulans}

Perhitungan unit cost dimulai dari penetapan unit produksi dan unit penunjang. Unit produksi adalah unit yang memproduksi barang/jasa yang akan dijual ke konsumen dan sebagai sumber pendapatan (revenue center), sedangkan unit penunjang adalah unit yang menunjang kegiatan di unit produksi dan tidak menerima pendapatan (cost center). Semua biaya termasuk biaya investasi, biaya operasional dan biaya pemeliharaan di setiap unit dihitung sehingga menghasilkan biaya asli per unit.Biaya asli di unit penunjang harus dialokasikan di unit produksi untuk memastikan bahwa unit cost yang terbentuk sudah mencakup biaya tidak langsung sehingga tarif yang ditetapkan pun akan mampu menutupi semua biaya yang dikeluarkan.

\section{PEMBAHASAN}

Sebagai salah satu Unit Pelaksana Teknis (UPT) Pemerintah DKI Jakarta, AGD Dinkes masih mendapatkan pembiayaan bersumber APBD dari Pemerintah Provinsi DKI Jakarta. Dari perhitungan total biaya evakuasi medis dengan metode double distribusi sebesar Rp.98.915.016.805,00 dibagi jumlah evakuasi medis di tahun 2018 sebanyak 37.564 kegiatan didapatkan unit cost evakuasi medis AGD Dinkes DKI Jakarta satu kali perjalanan adalah Rp.2.633.215,00 apabila tanpa subsidi biaya APBD sedangkan apabila komponen subsidi dimasukan dalam perhitungan didapatkan unit cost untuk sekali perjalanan AGD Dinkes adalah Rp.604.071,00., masih jauh di atas tarif yang berlaku saat ini sebesar Rp.450.00,00 sehingga cost recovery rate (CRR) nya masih dibawah $100 \%$.

Faktor faktor dalam penetapan tarif yaitu besaran unit cost, margin yang diharapkan, tarif pesaing, kemampuan dan kemauan masyarakat untuk membeli dan kebijakan termasuk visi yang dimiliki oleh sebuah organisasi. Berdasrkan focus grup discussion dengan managemen AGD Dinas Kesehatan ditetapkan: 
- Inflasi tahun 2018 sebesar 3,13\%

- Perkiraan inflasi tahun 2019 sebesar $3,53 \%$

- Margin 7,5\%

- Data tarif pesaing

- Pemilihan dasar unit cost yang digunakan (all cost atau cost minus subsidi APBD)

\begin{tabular}{|c|c|c|}
\hline \multicolumn{2}{|c|}{ Retokxuctist } & 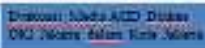 \\
\hline TABPF LAUTA4 & & Resucenes. \\
\hline \multirow{2}{*}{ LCtuss } & ALE cout & 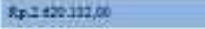 \\
\hline & 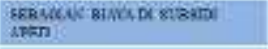 & Rrowiacien \\
\hline Javer basiado & & $7,000,0500,00-84,580,000,00$ \\
\hline stavers & & 390 \\
\hline \multirow{2}{*}{ Intus Takd } & Ant oset & Fol $114+7900$ \\
\hline & 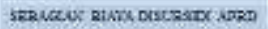 & Resesporace \\
\hline \multirow{2}{*}{ 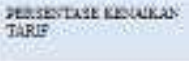 } & all cosst & $2 a 54$ \\
\hline & 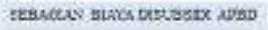 & $23=$ \\
\hline
\end{tabular}

Gambar1 Simulasi Tarif Evakuasi Ambulans

Dengan memperhatikan hal hal diatas maka tarif evakuasi medis AGD Dinkes dalam kota Jakarta untuk satu kegiatan dapat ditetapkan sebesar Rp.1,114.782,00 dengan menghitung semua biaya, dan Rp.689.919,00 dengan mengurangi biaya bersumber subsidi APBD. Adapun tarif evakuasi medis pesaing berada disekitar Rp.650.000,00 Rp.800.000,-. Ketika mengetahui tarif pesaing sangat dimungkinkan AGD Dinkes untuk menetapkan tarif baru diimbangi dengan efisiensi di masingmasing unit

\section{KESIMPULAN}

Setelah dilakukanan analisis biaya, didapatkan bahwa tiga komponen biaya AGD Dinkes Provinsi DKI Jakarta yaitu biaya investasi, operasional, dan pemeliharaan. Proporsi terbesar adalah biaya operasional sebersar $76 \%$. Belanja pegawai menacapai $80 \%$ dari keseluruhan biaya operasional.Adapun Cost Recovery Rate (CRR) tarif yang sudah ada saat ini masih belum mencapai 100\% sehingga tarif yang ada belum menutupi biaya yang dikeluarkan.

\section{REFERENSI}

Arsyansyah Hs, F. (2019). Analisis Metode Activity Based Costing dalam Perhitungan Unit Cost Pelayanan Rawat Inap pada Puskesmas Daerah Istimewa Yogyakarta (Studi Kasus pada Puskesmas Kabupaten Sleman, Provinsi Daerah Istimewa Yogyakarta). STIE YKPN.

Gani, H. S. (n.d.). Biaya Riset Dan Pengembangan Perlakuan Akuntansi Serta Pelaporannya Untuk Manajemen.

Horngren, Charles T., Srikant M. Datar, dan George Foster. (2006). Cost Accounting: A Managerial Emphasis. 12th edition. Pearson Prentice Hall. New Jersey.

Kemenkes RI. (2016). Peraturan Menteri Kesehatan Republik Indonesia Nomor 19 Tahun 2016 Sistem Penanganan Gawat Darurat Terpadu. Kementerian Kesehatan RI.

Mulyadi. 2007. Activity-Based Cost System: Sistem Informasi Biaya untuk Pemberdayaan Karyawan, Pengurangan Biaya, dan Penentuan Secara Akurat Kos Produk dan Jasa. Edisi 6. UPP STIM YKPN YOGYAKARTA, Yogyakarta 
Pemerintah Provinsi DKI Jakarta. (2015).

Peraturan Gubernur Provinsi Daerah

Khusus Ibukota Jakarta No 209

Tentang Tarif Pelayanan Ambulans

Gawat Darurat

Pemerintah Provinsi DKI Jakarta. (2016).

Peraturan Gubernur Provinsi Daerah

Khusus Ibukota Jakarta. No 384

Tentang Pembentukan Organisasi dan

Tata Kerja Unit Pelayanan Ambulan

Gawat Darurat

Sari, I. D., Herman, M. J., Susyanty, A. L., \& Su'udi, A. (2018). Analisis Biaya Tuberkulosis Paru Kategori Satu Pasien Dewasa di Rumah Sakit di DKI Jakarta. Jurnal Kefarmasian Indonesia, $8(1)$. https://doi.org/10.22435/jki.v8i1.6200 .44-54

Wita, Virna. 2012. Perhitungan Biaya Satuan Tindakan Bedah Appendiktomi Akut di Kamar Operasi Rumah Sakit X Tahun 2010. Thesis. Depok: Universitas Indonesia 